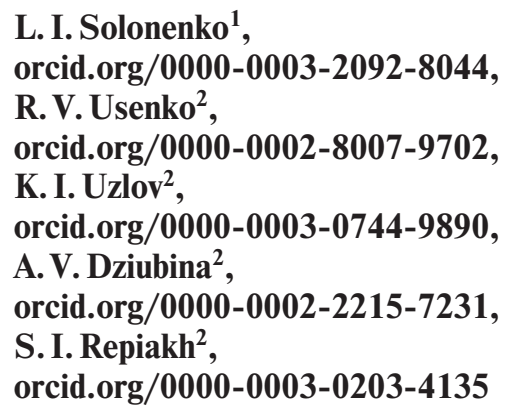

\title{
CARBONIZATION AND CRUSHABILITY OF STRUCTURED SAND-SODIUM-SILICATE MIXTURES
}

Purpose. To identify the regularities of kinetics of carbonization process in thin layers of solidified sodium-silicate solution and to describe the mechanism of changes in surface strength of structured sand-sodium-silicate mixtures as per time.

Methodology. Determination of ultimate compressive strength and crushability resistance was carried out on samples with dimensions of $\varnothing 50 \times 50 \mathrm{~mm}$. The samples were prepared from mixtures of quartz sand and $5 \%$ by weight of binder material (sandsodium-silicate mixture, phenol-formaldehyde resin), as well as quartz sand cladding with sand-sodium-silicate mixture. Sandsodium-silicate mixture carbonization kinetics was studied in a layer of hollow glass balls, previously clad with liquid sodium sand-sodium-silicate mixture. Excerpt and determination of ball mass as per duration of their staying in the air were carried out in a climatic chamber. Ball surface appearance was recorded by microscopic photographing with an up to 25 times magnification. Influence of materials-modifiers on dehydrated sodium silicate solute carbonization was investigated by visual assessment of cladding layer surface of glass balls. For this matter, glass balls of $\varnothing 10 \mathrm{~mm}$ were cladded with pure or modified sodium silicate solute followed by air drying for 6 hours. Cladding layer surface quality was evaluated after 48 hours of exposure in the climate chamber at $24-28{ }^{\circ} \mathrm{C}$ with $60-85 \%$ relative humidity.

Findings. With increasing short-term storage (up to 24 hours) of structured sand-sodium-silicate mixtures in air, their strength increases and crumbling decreases. With long-term storage - strength decreases and crumbling increases. Storage of prepared sand-sodium-silicate mixtures should be carried out in a hermetically sealed container using a portion of sodium hydroxide. For the first time, kinetics of sodium-silicate mixtures carbonization in a layer $\sim 20 \mu \mathrm{m}$ thick has been established. Based on the experimental data, kinetic curves for sodium silicate solute in clad layer carbonization are constructed. The reasons of extremum on kinetic curves presence are considered. Analytical expression for dependence of structured sand-sodium-silicate mixture crushability on the time of their staying in air has been developed. It is established that, among technological additives in sodium silicate solute tested in the work, no additive prevents or slows down the process of dehydrated sodium silicate solute in clad layer carbonization.

Originality. For the first time, kinetics of sodium-silicate mixture carbonization in a layer about $20 \mu \mathrm{m}$ thick has been investigated. It has been established that the process of sodium-silicate mixture carbonization begins without an induction period and is of an extreme nature. For the first time, analytical dependence of structured sand-sodium-silicate mixture crushability as per time they excerpt in air has been elaborated.

Practical value. Recommendations for long-time storage of granular materials containing finely dispersed sodium silicate or clad with sodium silicate have been developed. Implementation of the recommendations will allow reducing technological losses, improving the work on strengthening soils with sodium-silicate mixture quality and improving the quality of concrete and castings produced in sand-sodium-silicate mixture forms.

Keywords: carbonization, sand-sodium-silicate mixtures, air, water, crushability, carbon dioxide, humidity, strength

Introduction. Using of sodium silicate solute as binder material in many cases is economically feasible and technically effective. However, the fragmentary nature the known data on sodium silicate solute properties and their changing over time and under certain conditions and variety of areas of application of alkali metals silicates do not allow obtaining an accurate prognosis of the results of using this material in the long term period. As a result, the positive effect achieved from sodium silicate solute initial use is not always preserved, which can lead to significant financial and material consumption. In this regard, investigations aimed at solving the problem of studying the changes in alkali metal silicate properties in their long term using are relevant.

Literature review. Sodium silicate water solutions (sodium silicate solute) are currently widely used both for household goods and for mining rock silicification, soil strengthening, acid-resistant and heat-resistant mortars and concrete production, putties, glues, adhesives [1], foam materials [2, 3],

(C) Solonenko L.I., Usenko R.V., Uzlov K.I., Dziubina A.V., Repiakh S. I., 2020 adsorbents [4], in foundry industry for linings, foundry molds and cores, refractory adhesives manufacturing [5], and others. Such high multifunctionality of sodium silicate solute is due to complex of positive properties inherent exclusively to these materials. Nevertheless, like any other material, sodium silicate solute has certain disadvantages. In particular, in relation to foundry, properties of molds and cores based on sodium silicate solute are highly dependent on the methods and conditions of their manufacture, on the duration and storage conditions, on the mode of physical and temperature effects on them from the side of the casting, and so on $[5,6]$. One of foundry molds and cores quality indicators is their crushability $(\mathrm{CrAb})-$ i.e. molding and core mixtures' (MCM) technological property, which characterizes the surface layer of mold/ core ability not to be ruined upon external (manipulation, installation into the mold, filling the mold with melt, and others) mechanical impact on it. Crushability is characterized by the value of sample mass from structured MCM decreasing during its abrasion in a certain way for 1 minute, expressed in $\%$. Wherein, it is believed that crushability of MCM samples is satisfactory if, according to the test results, CrAb £ 0.1-0.2\% 
[7]. Casting crushability increasing enhances the probability of growing numbers and size of blockages, local mold collapses, nonconformance in geometry between casting shape and its model, and others.

Crushability of disposable sand molds/rods depends on a significant number of factors, including $[7,8]$ :

- the nature of mixture components;

- mixture fractional composition of granular refractory material in MCM;

- the amount of binder material in the mixture, its properties and method of solidification;

- technological additives in MCM type and quantity;

- MCM humidity and binder hygroscopicity;

- method of MCM structuring and drying;

- mixture, finished molds/cores shelf life, and others.

In particular, Wang Jina, et al. [2009] investigated properties of sand-sodium-silicate mixtures solidified as a result of microwave radiation, carbon dioxide purging, as well as sodium silicate solute saturation with ether. The authors found that sodium silicate solute solidification by microwave radiation allows obtaining sand-sodium-silicate mixtures with 1.5$2.0 \%$ by weight of sodium silicate solute with compressive strength the same as that of a mixture solidified with ether with 2.5-3.5\% sodium silicate solute, and solidified with carbon dioxide with 5-6\% sodium silicate solute. One of the problems of sand-sodium-silicate mixtures, which were structured by microwave radiation, is their ability to absorb moisture from surrounding air. With the mass of sodium silicate solute in the mixture before its solidification increasing, the mass of the moisture absorbed by sand-sodium-silicate mixtures after structuring with microwave radiation also increases. This phenomenon, according to Wang Jina and his staff, leads to significant increasing of molds/cores crushability, as well as to their compressive strength decreasing. In addition, when using microwave furnace with magnetron output power of 700 to $2000 \mathrm{~W}$, compressive strength of sand-sodium-silicate mixtures after their structuring and after heating to $800{ }^{\circ} \mathrm{C}$ does not significantly depend on furnace magnetron power and the mixture solidification time in it but substantially depends only on sodium silicate solute content in the mixture.

It is generally accepted that MCM crushability mainly depends on its strength and binder material hygroscopicity. At the same time, authors [9] recommended calculating MCM crushability value using the formula

$$
\mathrm{CrAb}=z_{0} \cdot K \cdot \mathrm{s}^{-1},
$$

where $z_{o}$ is correction factor; $K$ is MCM gas permeability; $s$ is MCM compression (tension) ultimate strength.

According to formula (1), there is direct proportional linear relationship between the crushability value and gas permeability to compressive (tension) strength of mixtures. Moreover, this regularity is inherent for structured mixtures with binder material of both inorganic and organic nature, which follows from behavior of dependencies in Fig. 1. Fig. 1, $a$ shows the relationship between calculated $\left(\mathrm{CrA} \mathrm{b}_{\text {calc. }}\right)$ and experimental $\left(C r A b_{1}\right)$ crushability values of sodium silicate solute structured mixture $(1,2)$, obtained by experimental data processing from Patents RU No. 1404152 and No. 2038182, respectively.

Fig. 1, $b$ presents similar dependence for structured mixture based on aluminochromophosphate (3) - Patent RU No. 2041765 and based on technical lignosulfonates mixture, postyeast residue of feed yeast production and molding clay (4) Patent RU No. 2017554.

Fig. 1, $c$ shows the relationship on the basis of dusty-type periclase and phosphoric acid in silicasol solution (Patent RU No. 1766575). In Fig. 1, $d$ there is a relationship on the basis of polyfuryl alcohol in the form of synthetic resin, or triethanolamine, or ethylene diamine with catalyst - benzolsulfonic acid water solution (Patent RU No. 967666).

Between well-known binders from environmental safety and sanitary standards point of view, cost of production and

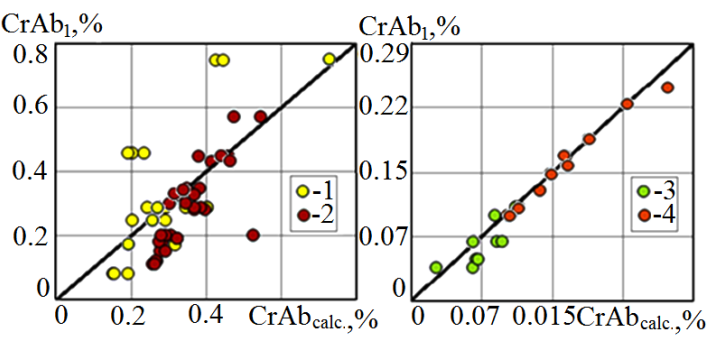

$a$

$b$

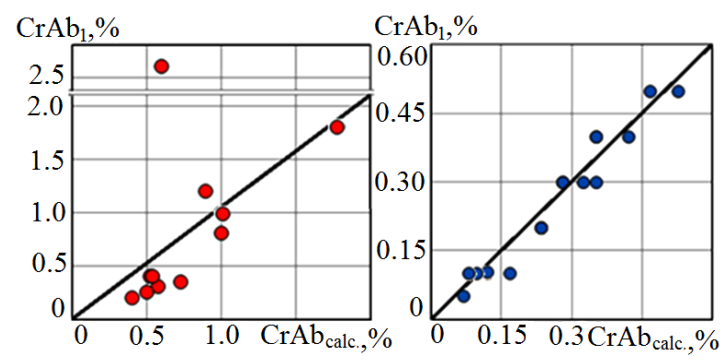

$c$

$d$

Fig. 1. Relationship between the value calculated $\left(C r A b_{\text {calc. }}\right)$ by formula (1) and experimental $\left(C r A b_{1}\right)$ value of crushability of samples from quartz sand with sodium silicate solute mixture (a), aluminochromophosphate, technical lignosulfonates mixture, post-yeast residue of feed yeast production and molding clay (b), dusty-type periclase and phosphoric acid in silicasol solution $(c)$, polyfuryl alcohol $(d)$ :

1 - Patent RU No. 1404152; 2 - Patent RU No. 2038182; 3 Patent RU No. 2041765; 4 - Patent RU No. 2017554

disposal of waste, sodium silicate solute is most preferable $[7,10]$.

Nevertheless, sodium silicate solute also has a number of significant technological disadvantages, including their carbonization upon holding in air.

Aqueous solutions of sodium silicate using in engineering and technology has been dealt with by many scientists and researchers, including S. S. Zhukovsky, Yu. P. Vasin, P. P. Berg, D. M. Kukuy, A. M. Lyass, P. A. Borsuk, et al. [11, 12].

Nevertheless, at the present time, carbonization kinetics in thin layers of solidified sodium silicate solute has not been studied. There is no analytical description of dependence of crushability value of structured sand-sodium-silicate mixtures on time and their exposure to air. Relative humidity influence on carbonized surface appearance, and so on, has not been discovered.

In conclusion, it should be noted that carbonization is not an undesirable process in all cases. In particular, carbonization of sodium silicate aqueous solution is deliberately carried out to obtain high purity amorphous $\mathrm{SiO}_{2}[13]$ and in foundry industry for sand-sodium-silicate foundry molds and cores solidification, and others.

Purpose. The purpose of the work is to study carbonization process kinetics in thin layers of solidified sodium silicate solute and to develop ways for this process prevention, to investigate the effect of storage time and relative air humidity on the crushability value of structured sand-sodium-silicate mixtures.

Methods. Cylindrical shape samples with dimensions of $\varnothing 50 \times 50 \mathrm{~mm}$ were used to determine crushability of structured mixtures, compressive strength, and gas permeability. Crushability was determined in accordance with GOST 23409.9-78. Compressive strength of structured mixtures was determined in accordance with GOST 8462-85, gas permeability - in accordance with GOST 23409.6-78.

To study sodium silicate solute in air carbonization kinetics, a layer of sodium silicate solute with specific gravity of 
$1440 \mathrm{~kg} / \mathrm{m}^{3}$ and with silicate modulus of 2.9 was applied to the surface of balls $\varnothing 50 \mathrm{~mm}$ by dipping, which provided a liquid layer with thickness of about $30 \mu \mathrm{m}$ and a layer of partially dehydrated sodium silicate solute with about $20 \mu \mathrm{m}$ thickness. The balls prepared in this way were placed in a climatic chamber with certain relative air humidity. For 8 days with frequency of 7 hours, their weight was determined on electronic balance with an accuracy of $0.01 \mathrm{~g}$. Relative humidity and air temperature were measured using a TA-318 electronic thermometer-hygrometer.

In order to reduce relative humidity of the air to $W=23-$ $25 \%$ and to reduce the carbon dioxide content in the air, dry sodium hydroxide $(\mathrm{NaOH})$ was placed in the climate chamber.

In order to estimate the influence of modifying materials on dehydrated sodium silicate solute in thin layer carbonization, a layer with $\sim 30 \mu \mathrm{m}$ thickness of pure and modified sodium silicate solute was applied to glass balls surface with a $10 \mathrm{~mm}$ diameter. Cladding layers were dried in air at relative humidity of $35-45 \%$ and temperature of $32-35{ }^{\circ} \mathrm{C}$ for 6 hours. After that, the balls were placed in climate chamber with relative air humidity of $W=60-85 \%$ and temperature of 24-28 ${ }^{\circ} \mathrm{C}$ for 48 hours.

Results. Structured mixture crushability in air changes monotonically ambiguously with time increasing and depends on the nature of binder material in the mixture, as evidenced by dependences in Fig. 2. Fig. 2 shows dependences of samples' crushability $(\mathrm{CrAb})$ and compressive strength $\left(\sigma_{S T}\right)$ on exposure time $(\tau)$ in air. Similar dependences (Fig. 2) are most characteristic for majority of used MCM. But storage of, for example, quartz sand clad with sodium silicate solute in hermetically closed container does not solve the problem of its technological properties at initial level preservation.

This, in particular, is indicated by the data in Table 1, which shows the values of compressive strength and crushabil- ity of structured quartz sand samples, clad with $2 \%$ (by weight) sodium silicate solute with density of $1440 \mathrm{~kg} / \mathrm{m}^{3}$ with silicate modulus of 2.9 .

According to Fig. 2, $a$, from the moment when structuring is completed, mixture strength increases with increasing exposure time in air, which is due to finalizing of binder material solidification (polymerization), and crushability decreases, which also follows from formula (1).

The most noticeable strength enhancement and the lowest crushability for any type of mixtures were observed in the first 24 hours from the moment of removing the foundry rig. Further, structured MCM strength increases slightly, which is apparently due to stress relaxation in the MCM. At the same time, in sand-resin mixtures, crushability practically does not change (Fig. 2,a), while in sodium silicate solute MCM, it increases noticeably (Fig. 2, b).

To explain the described course of dependencies in sandsodium-silicate MCM, let us note the following types of strength:

- primary strength - minimal strength of MCM, at which, without molds/rods breaking, it is possible to remove them from the rigging and carry out certain types of manipulations with them and subsequent technological operations;

- handling (required strength) - maximum strength of MCM, which molds/rods acquire after, as a rule, 24 hours from the moment they are removed from the rig;

- long-term strength - molds/rods strength after a long (more than one day) storage in air.

Based on the definitions above, it can be said that the above discussed dependences of crushability behavior on exposure time of sand-sodium-silicate MCM in air (Fig. 2, $b$ ), is conditioned by the time change in the state of binder material cuffs formed between sand grains of MCM during its structuring. That is, after compacting in rig between sand grains,
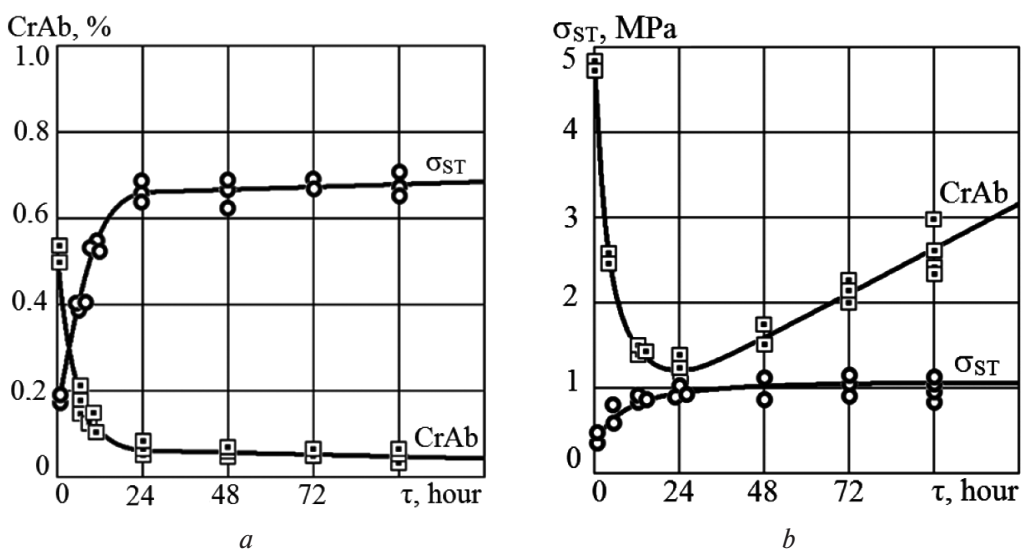

Fig. 2. Dependence of crushability and compressive strength of samples structured by heating for 60 sec at $220-230^{\circ} \mathrm{C}$ of quartz sand with $5 \%$ furan resin FF-1C (a) mixture and samples from quartz sand with $5 \%$ water glass mixture, structured according to $\mathrm{CO}_{2}$ process (b) on exposure time in air with relative humidity of $62 \%$

Table 1

Properties of structured quartz sand clad with $2 \%$ (by weight) sodium silicate solute samples, prepared after storage in hermetic container

\begin{tabular}{|l|l|c|c|c|c|c|}
\hline \multirow{2}{*}{$\begin{array}{c}\text { Structured mixture } \\
\text { parameter }\end{array}$} & \multirow{2}{*}{$\begin{array}{c}\text { Units of } \\
\text { measurement }\end{array}$} & \multicolumn{5}{|c|}{ Value of samples indicators prepared from clad sand, which were stored in a hermetic container } \\
\cline { 3 - 7 } & & 0 months & 3 months & 6 months & 9 months & 12 months \\
\cline { 3 - 7 } & dimensionless & $175 \pm 4$ & $180 \pm 7$ & $193 \pm 7$ & $202 \pm 12$ & $230 \pm 15$ \\
\hline$\sigma_{S T}$ & $\mathrm{MPa}$ & $2.7 \pm 0.2$ & $1.2 \pm 0.2$ & $0.6 \pm 0.1$ & $0.13 \pm 0.05$ & $0.02 \pm 0.01$ \\
\hline$C r A b$ & $\%$ & $0.13 \pm 0.02$ & $0.3 \pm 0.04$ & $0.68 \pm 0.11$ & $4.2 \pm 1.0$ & $22 \pm 5$ \\
\hline
\end{tabular}

Note: $K$ - Gas permeability. Storage was carried out in Dacron barrels. Cladding sand was sealed at relative humidity of $62 \%$. Barrel filling with clad sand $-99 \%$ by volume. Storage temperature $-15-25^{\circ} \mathrm{C}$ 
"cuffs" are formed from liquid binder material, which is shown schematically in scheme in Fig. 3, $a$.

After blowing the MCM with carbon dioxide, a layer of solid silicic acid appears in addition to sodium carbonate and hydro carbonate on the cuff surface as a result of $\mathrm{Na}_{2} \mathrm{O}$ sodium silicate solute (Fig. 3,b) carbonization. This layer appearance helps to mixture structuring and gives it primary strength.

After extracting the structured MCM from the rig, water evaporates. Removing water from MCM leads to solidifying of remaining sodium silicate solute in cuffs (Fig. 3, c). Dehydration of sodium silicate solute remaining in the cuffs increases molds/cores strength, practically, to its maximum value. That is, after 24 hours, molds and cores acquire the necessary (maximum) handling strength.

If such forms and cores continue to be held in air, this leads to continuation and completion of carbonization process of solidified part of sodium silicate solute remaining in the cuffs (Fig. 3, $d$ ). Moreover, since silicic acids strength is lower than strength of sodium silicate solute solidified from dehydration, strength of MCM in the surface layer of the samples decreases. Accordingly, with decreasing strength of the surface layer, its crushability also increases.

If it is assumed that change in the value of crushability in first 24 hours can be described by exponential dependence, and subsequently by a power-law dependence, then equation for calculating the value of crushability as function of structured sand-sodium-silicate sample exposure time in air will have the form, $\%$ (by weight)

$$
\operatorname{Cr} A b(t)=A-\exp (b \cdot \tau)^{C}+(d \cdot \tau)^{F},
$$

where $A$ is free term of equation numerically equal to crushability value at the time of extracting the sample from a core box, $\%$ (by weight); $b, d$ are coefficients, $\% / \mathrm{h} ; C, F$ are exponents; $\tau$ is exposure time of the sample in air from the moment of its extraction from the core box, $h$.

The results of calculating CrAb by (2) for sand-sodiumsilicate samples prepared by $\mathrm{CO}_{2}$ process in the case considered above are presented in Fig. 4.

It follows from foregoing that the cause of crushability of structured sand-sodium-silicate mixtures is the process of sodium silicate solute carbonization, which is caused by chemisorption of moisture and carbon dioxide from the air on the surface of sodium silicate solute cuffs binding sand particles together. In this case, carbonization process can be described by the following equations

$$
\begin{gathered}
\mathrm{Na}_{2} \mathrm{O} \cdot 3 \mathrm{SiO}_{2}+\mathrm{CO}_{2}+6 \mathrm{H}_{2} \mathrm{O} \rightarrow \mathrm{Na}_{2} \mathrm{CO}_{3}+3 \mathrm{H}_{4} \mathrm{SiO}_{4} \\
\mathrm{Na}_{2} \mathrm{O} \cdot 3 \mathrm{SiO}_{2}+2 \mathrm{CO}_{2}+7 \mathrm{H}_{2} \mathrm{O} \rightarrow 2 \mathrm{NaHCO}_{3}+3 \mathrm{H}_{4} \mathrm{SiO}_{4} \\
\mathrm{Na}_{2} \mathrm{O} \cdot 3 \mathrm{SiO}_{2} \cdot 3 \mathrm{H}_{2} \mathrm{O}+\mathrm{CO}_{2}+3 \mathrm{H}_{2} \mathrm{O} \rightarrow \mathrm{Na}_{2} \mathrm{CO}_{3}+3 \mathrm{H}_{4} \mathrm{SiO}_{4} \\
\mathrm{Na}_{2} \mathrm{O} \cdot 3 \mathrm{SiO}_{2} \cdot 3 \mathrm{H}_{2} \mathrm{O}+2 \mathrm{CO}_{2}+4 \mathrm{H}_{2} \mathrm{O} \rightarrow \\
2 \mathrm{NaHCO}_{3}+3 \mathrm{H}_{4} \mathrm{SiO}_{4}
\end{gathered}
$$

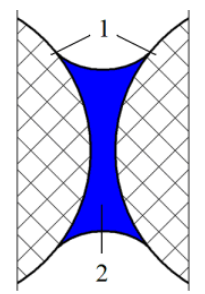

$a$

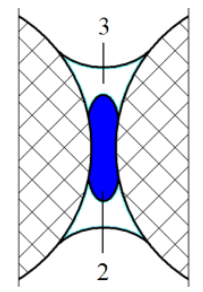

$b$

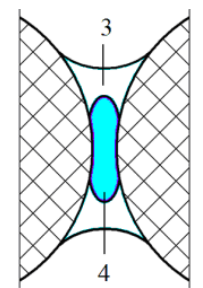

$c$

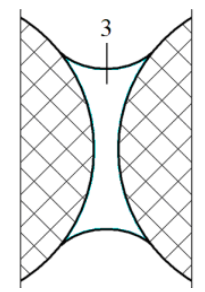

$d$
Fig. 3. Schemes of stages of changing intergranular cuffs of binder material in MCM structure:

1 - sand grains of refractory mixture material; 2 - cuff from aqueous solution of sodium silicate (sodium silicate solute); 3 - solid carbonized cuff layer; 4 - partially dehydrated sodium silicate (solidified dehydrated sodium silicate solute)

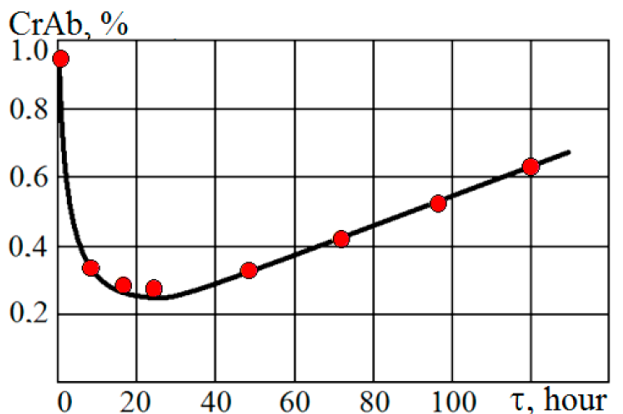

Fig. 4. Dependence of crushability of sand-sodium-silicate samples on its exposure to air time from manufacturing time (points - calculations by formula (2))

According to (3-6), not only sodium carbonates or bicarbonate is formed as a result of carbonization, but also waterinsoluble ortho-silicic acid. Over time, the chemically unstable compound (ortho-silicic acid), which has appeared, can be poly-condensed, turning into di-silicic or pyro-silicic acid with water releasing

$$
\begin{aligned}
2 \mathrm{H}_{4} \mathrm{SiO}_{4} & \rightarrow \mathrm{H}_{2} \mathrm{Si}_{2} \mathrm{O}_{5}+3 \mathrm{H}_{2} \mathrm{O} \\
2 \mathrm{H}_{4} \mathrm{SiO}_{4} & \rightarrow \mathrm{H}_{6} \mathrm{Si}_{2} \mathrm{O}_{7}+\mathrm{H}_{2} \mathrm{O}
\end{aligned}
$$

Carbonization kinetics in the air was studied by determining the mass of a thin layer of sodium silicate solute changing over time. The thin layer was applied to the surface of $\varnothing 50 \mathrm{~mm}$ hollow glass balls. The results of the studies conducted are presented in corresponding dependencies form in Fig. 5.

The analysis of dependencies in Fig. 5 shows that the sodium silicate solute carbonization process has no induction period. Change in the mass of a layer of partially dehydrated sodium silicate solute is extreme. That is, from the moment when drying of sodium silicate solute layer is finished and measurements are begun, the layer mass increases, which indicates that carbonization order is in accordance with equations $(5,6)$.

With relative humidity increasing, the carbonation rate and mass of forming carbonate and bicarbonate increase. Further exposure of the balls in the climate chamber leads to their mass decreasing, regardless of air relative humidity. This mass decreasing could be explained by carbonization reactions $(5$, $6)$ completion and poly-condensation reactions advancing ( 7 , 8 ) and with water releasing during di-silicic or pyro-silicic acids formation.

At the relative air humidity of $24 \%$, the decrease in sodium silicate solute mass is so great that after 2.5 days of exposure in the climatic chamber, the balls' mass becomes less than their initial mass (Fig. 5). Apparently, such regularity is related to slight sodium silicate solute carbonization, which is caused by carbon dioxide in air absorption by sodium hydroxide, water evaporation during poly-condensation of ortho-silicic acid formed and dehydration of remaining sodium silicate solute.

In the poly-condensation process, higher silicic acids form complex (linear, branched, mixed) spatial structures. In the

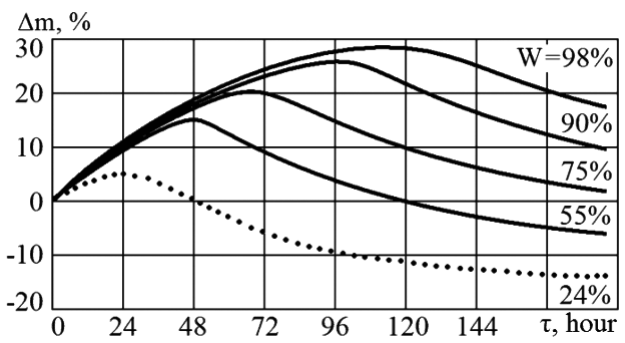

Fig. 5. Dependence of sodium silicate solute layer relative mass changing on exposure time in air and its relative humidity 
thin layer of solidified sodium silicate solute on surfaces with large radius of curvature, silicic acids, being a structural material component, should demonstrate themselves as colorless films of various textures and sizes, and sodium carbonate (bicarbonate) - in white plaque form or separate white crystals on carbonized layer surface. Confirmation of the above involves photographs of the carbonized surface of the clad layer on the balls after 5 days (Fig. 6) and after 10 days (Fig. 7) of their exposure in the climate chamber.
It should be noted that at the relative humidity of $24 \%$ and low carbon dioxide content in the air, the sodium silicate solute layer practically did not carbonize either after 5 days (Fig. 6, $a$ ) or after 10 days (Fig. 7). At the same time, cracks in the layer appeared after 5 days, and after 10 days, apparently due to the high degree of dehydration, the layer exfoliated from the ball surface (Fig. 7, a).

Carbonization of clad with sodium silicate solute sand after its structuring also leads to crushability increasing and

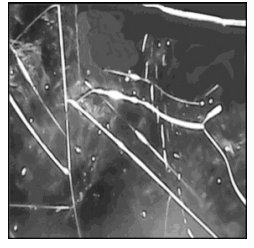

$a$

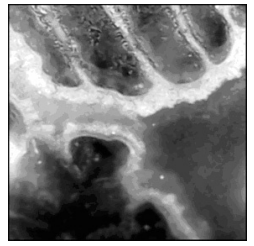

$b$

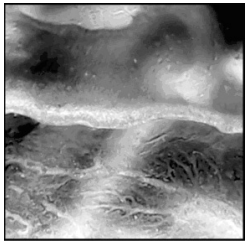

$c$

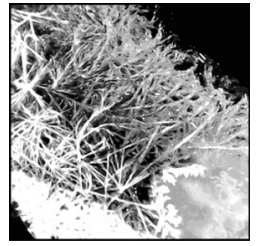

d

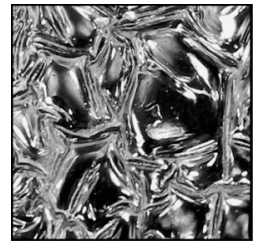

$e$

Fig. 6. Carbonized surface structure of sodium silicate $(\times 25)$ after 5 days in air with relative humidity: $a-24 \% ; b-55 \% ; c-75 \% ; d-90 \% ; e-98 \%$

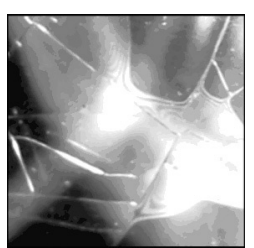

$a$

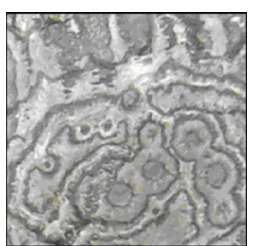

$b$

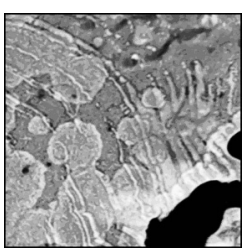

$c$

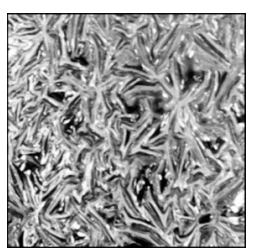

$d$

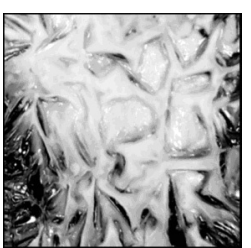

$e$

Fig. 7. Carbonized surface structure of sodium silicate $(\times 25)$ after 10 days in air with relative humidity:

$a-24 \% ; b-55 \% ; c-75 \% ; d-90 \% ; e-98 \%$

Sodium silicate solute modifiers

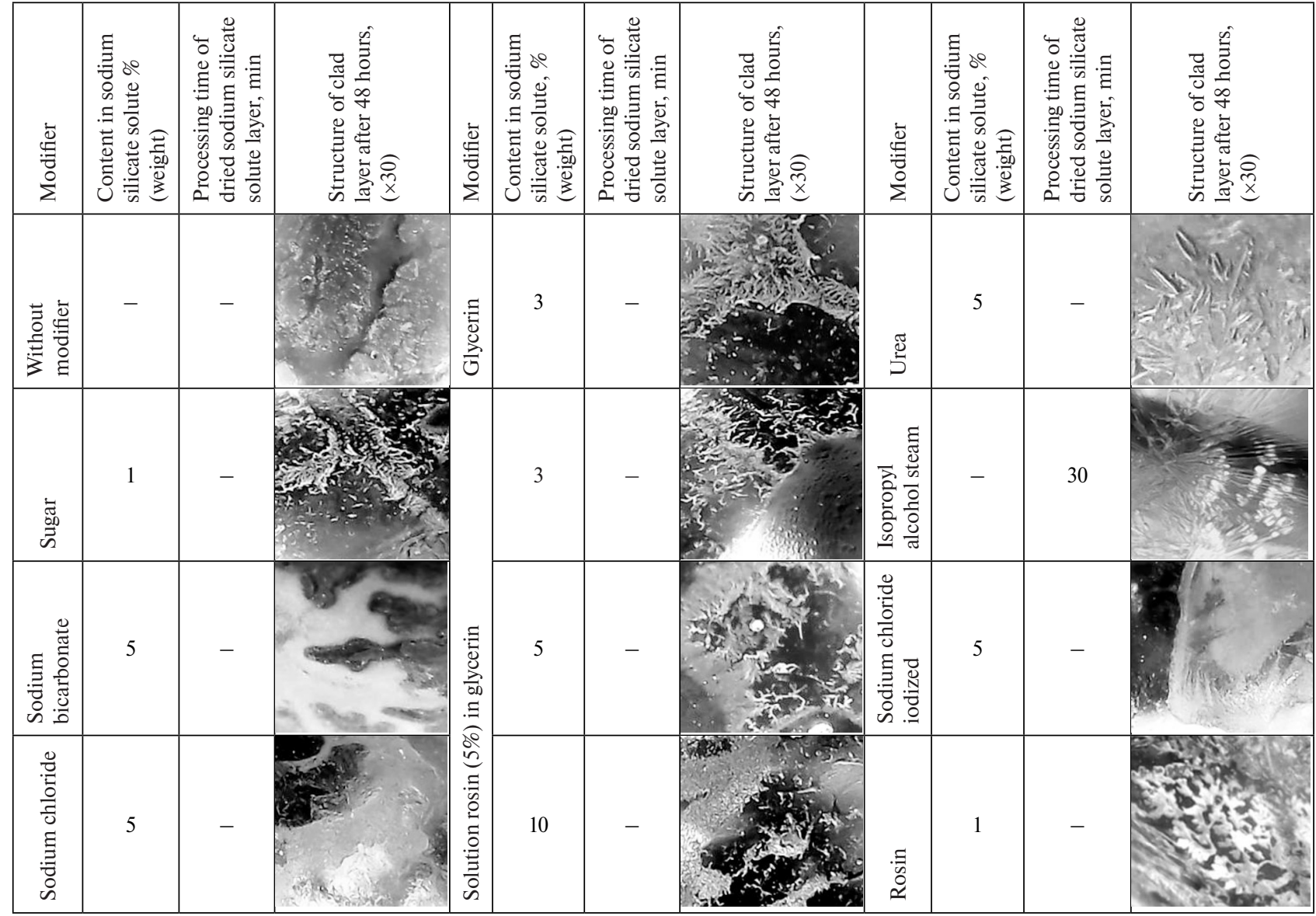


strength of products made from it decreasing. In order to preserve high technological effectiveness, sand clad with sodium silicate solute or powdered sodium silicate should be stored in hermetically sealed containers. To carry out dehydration and prevent sodium silicate solute carbonization, dry caustic soda should be placed in hermetically sealed containers.

One of significant drawbacks of sodium silicate solute as a binder for manufacturing foundry molds/cores is difficulty in knocking sand-sodium-silicate mixtures out of castings. In order to reduce energy consumption for knocking sand-sodiumsilicate mixtures out of castings, appropriate technological additives are added to it before using sodium silicate solute. Among these additives are water-soluble substances of organic origin - compounds of carbon chain unsaturated structure with high carbon content (pitch, sugar, thermoplastic coals), as well as sugar-containing materials and their derivatives (starch, glycerin, green molasses). For the same purpose, ammonium sulfate, sodium sulfate, ammonium salt, urea, rosin, dextrin, pulver bakelite, and others are added to sodium silicate solute [14]. Since aqueous sodium silicate solutions are classified as chemically active materials, the introduction of any other material into the initial sodium silicate solute will properly reflect not only properties of dehydrated sodium silicate solute, but also its carbonization process.

As test modifiers, materials were used, whose names, as well as type of clad layer after 48 hours exposure in climate chamber are given in Table 2.

The analysis of surface appearance of the balls clad layer after 48 hours in the climate chamber shows that no modifier used in this work prevents the process of sodium silicate solute carbonization.

Conclusions. For the first time, carbonization kinetics of partially dehydrated sodium liquid glass in a thin layer in the air has been studied. It was found that carbonization process kinetic curves have an extremum, whose appearance is due to two successive processes - sodium dioxide carbonization and silicic acid poly-condensation. With relative humidity increasing, carbonization intensity and mass of carbonate and bicarbonate formed in sodium silicate solute thin films increase. Storage of prepared sand-sodium-silicate mixtures should be carried out in a hermetically sealed container using caustic soda portion.

For the first time, analytical expression for structured sand-sodium-silicate samples crushability amount dependence on exposure time in air has been obtained.

For the first time, description of a mechanism for changing surface strength of structured sand-sodium-silicate mixtures in time has been developed.

The use of sodium silicate solute modifiers did not prevent the process of its carbonization.

Application of the presented results will allow expanding the understanding and knowledge concerning the processes associated not only with structuring, but also with long-term storage of bulk materials and products, reducing technological losses and improving the quality of procedures associated with the use of sodium silicate solute.

\section{References.}

1. Zhuginisov, M.T., \& Kazimir, S. V. (2015). Analytical review of the technology of the technology of refractory concrete on the basic Solid sodium silicate. Vestnik KazNTU, 3(109), 428-433. ISSN 1680-9211.

2. Abdrakhimov, V.Z., Abdrakhimov, E.S., \& Abdrakhimov, I. D. (2017). Getting insulating material based in liquid glass and coal conversion wastes generated during coking coal preparation. Ugol - Russian Coal Journal, 4, 64-67. https:// doi.org/10.18796/0041-5790-2017-4-64-67.

3. Abdrakhimov, E.S. (2019). Use of waste fuel and energy complex - burned rocks and tailings of chromite ore in the production of porous aggregate on the basis of liquid-glass compositions. Ugol - Russian Coal Journal, 7, 67-69. https:// doi.org/10.18796/0041-5790-2019-7-67-69.
4. Kogan, V. E. (2016). Inorganic and organic vitreous foam materials and prospect of environmental cleaning from oil and oil products pollutions. Journal of Miming Institute, 218, 331337. ISSN 0135-3500.

5. Karateev, A. M., Ponomarenko, O.I., \& Berlizeva, T.V. (2018). Current trends in the use of liquid glass mixtures with ether hardeners. Equipment and tools for professionals, 2(204), 70-72.

6. Krutilin, A. N., Huminski, Yu. Yu., \& Rusevich, O.A. (2018). Improvement of efficiency of use of liquid-glass mixtures. Part 4. Combined strengthening. Foundry production and metallurgy, 4(93), 38-44. ISSN 1683-6065.

7. Tkachenko, S. S., Kolodiy, G. A., Znamensky, L. G., \& Ermolenko, A. A. (2018). Cold mixture of inorganic binder: status and prospects of development (inorganic vs. organic). Foundry production and metallurgy, 2(91), 16-22. ISSN 16836065.

8. Krutilin, A. N., Huminski, Yu. Yu., \& Kulbitskaya, L. V. (2018). Efficiency upgraging in utilization of liquid-glass mixtures. Part 2. Electro-physical methods of action. Foundry production and metallurgy, 2(91), 50-56. ISSN 1683-6065.

9. Solonenko, L. I., Bilii, O. P., \& Uzlov, K. I. (2018). Functional deposits between the authorities with the structured and formal sums. Theory and practice of metallurgy, 6, 93-100. ISSN 1028-2335.

10. Solonenko, L., Prokopovitch, I., Repyakh, S., Sukhoi, K., \& Dmytrenko, D. (2019). System analysis of modern areas of increasing environmental and sanitary hygienic safety of using cold hardening mixtures in foundry. Proceedings of Odessa Polytechnic University, 1(57), 90-98. https:// doi.org/10.15276/ opu.1.57.2019.11.

11. Grishina, A. N. (2017). Liquid-glass building materials for special purposes. Moscow: Publishing house MISI - MGSU. ISBN 978-5-7264-1526-0.

12. Hyminski, Yu. Yu., \& Rovin, S. L. (2019). Eco-friendly liquid-glass binder modified by ultra-dispersed materials. Foundry production and metallurgy, 3, 41-45. ISSN 1683-6065. 13. Muljani, S., Dewati, R., Suprihatin, \& Sumada, K. (2019). Precipitated Silica by Precipitation Process of The Sodium Silicate Solution with Carbon Dioxide Gas $\left(\mathrm{CO}_{2}\right)$ on Fixed Bed Column. International Seminar of Research Month Science and Technology for People Empowerment, 2018, 231-236. ISSN 2622-9692.

14. Krutilin, A.N., Guminsky, Yu.Yu., \& Rusevich, O.A. (2018). Improving the efficiency of the use of liquid-glass mixtures. Overview information. Part 1. Modification. Foundry production and metallurgy, 1(90). 47-54. ISSN 1683-6065.

\section{Карбонізація та обсипальність структурованих піщано-рідкоскляних сумішей}

\section{Л. І. Солоненко ${ }^{1}$, Р. В. Усенко ${ }^{2}$, К. І. Узлов ${ }^{2}$, A. В. Дзюбіна ${ }^{2}$, C. I. Pen'ях ${ }^{2}$}

1 - Одеський національний політехнічний університет, м. Одеса, Україна

2 - Національна металургійна академія України, м. Дніпро, Україна, e-mail: 123rs@ua.fm

Мета. Встановлення закономірностей кінетики процесу карбонізації в тонких шарах затверділого рідкого скла, і опис механізму зміни поверхневої міцності структурованих піщано-рідкоскляних сумішей у часі.

Методика. Визначення межі міцності при стисненні та обсипальності проводили на зразках $з$ розмірами $\varnothing 50 \times 50$ мм. Зразки виготовляли з сумішей кварцового піску і $5 \%$ за масою сполучного матеріалу (рідкого скла, фенол-формальдегіду), а також кварцового піску, плакованого рідким склом. Кінетику карбонізації рідкого скла 
в шарі досліджували на порожніх скляних кулях, попередньо плакував їх натрієвих рідким склом. Витримку і визначення маси куль від тривалості перебування їх на повітрі проводили в кліматичній камері. Вид поверхні куль фіксували фотозйомкою на мікроскопі при збільшенні до 25 крат. Вплив модифікуючих матеріалів на карбонізацію дегідратованого рідкого скла досліджували за результатами візуальної оцінки поверхні плакованих шарів скляних кульок. Для цього скляні кулі $\varnothing 10$ мм плакували чистим або модифікованим рідким склом 3 наступним сушінням на повітрі протягом 6 годин. Якість поверхні плакованих шарів оцінювали після 48 годин їх витримки у кліматичній камері при $24-28{ }^{\circ} \mathrm{C}$ із відносною вологістю повітря 60-85\%.

Результати. Зі збільшенням тривалості короткочасного зберігання (до 24 год) на повітрі піщано-рідкоскляних сумішей, що структурувалися, їх міцність зростає, а обсипальність знижується. При довготривалому зберіганні - міцність зменшується, а обсипальність зростає. Зберігання приготованих піщано-рідкоскляних сумішей слід проводити в тарі, яка герметично закривається, з використанням наважку гідроксиду натрію. Уперше встановлена кінетика карбонізації натрієвого рідкого скла в шарі товщиною близько 20 мкм. На основі експериментальних даних побудовані кінетичні криві карбонізації натрієвого рідкого скла у плакованому шарі. Розглянуті причини наявності екстремуму на кінетичних кривих. Розроблено аналітичний вираз залежності обсипальності структурованих піщано-рідкоскляних сумішей від часу їх находження на повітрі. Встановлено, що із числа випробуваних у роботі технологічних добавок, які додавали до рідкого скла, жодна добавка не запобігає й не уповільнює процес карбонізації дегідратованого рідкого скла у плакованому шарі.

Наукова новизна. Уперше досліджена кінетика карбонізації натрієвого рідкого скла в шарі товщиною близько 20 мкм на повітрі. Установлено, що процес карбонізації рідкого скла починається без індукційного періоду та носить екстремальний характер. Уперше розроблена аналітична залежність величини обсипальності структурованих рідкоскляних сумішей від часу перебування їх на повітрі.

Практична значимість. Розроблені рекомендації із тривалого зберігання зернистих матеріалів із пилоподібним силікатом натрію або плакованим силікатом натрію. Використання рекомендацій дозволить скоротити технологічні втрати та підвищити якість робіт зі зміцнення грунтів рідким склом, підвищити якість бетонів і лиття, виробленого в піщано-рідкоскляних формах.

Ключові слова: карбонізація, рідке скло, повітря, вода, обсипальність, вуглекислий газ, вологість, міцність

\section{Карбонизация и осыпаемость структурированных песчано-жидкостекольных смесей}

\section{Л. И. Солоненко ${ }^{1}$, Р. В. Усенко ${ }^{2}$, К. И. Узлов ${ }^{2}$, А. В. Дзюбина ${ }^{2}$, С. И. Репях ${ }^{2}$}

1 - Одесский национальный политехнический университет, г. Одесса, Украина

2 - Национальная металлургическая академия Украины, г. Днепр, Украина, e-mail: 123rs@ua.fm

Цель. Установление закономерностей кинетики процесса карбонизации в тонких слоях затвердевшего жидкого стекла, и описание механизма изменения поверх- ностной прочности структурированных песчано-жидкостекольных смесей во времени.

Методика. Определение предела прочности при сжатии и величины осыпаемости проводили на образцах с размерами $\varnothing 50 \times 50$ мм. Образцы изготавливали из смесей кварцевого песка и 5 \% по массе связующего материала (натриевого жидкого стекла, феноло-формальдегидной смолы), а также кварцевого песка, плакированного жидким стеклом. Кинетику карбонизации жидкого стекла в слое исследовали на полых стеклянных шарах, плакированных жидким стеклом. Выдержку и определение массы шаров от длительности нахождения их на воздухе проводили в климатической камере. Вид поверхности шаров фиксировали фотосъёмкой на микроскопе при увеличении до 25 крат. Влияние модифицирующих материалов на карбонизацию дегидратированного жидкого стекла исследовали по результатам визуальной оценки поверхности плакированного слоя стеклянных шаров. Для этого стеклянные шары $\varnothing 10$ мм плакировали чистым или модифицированным жидким стеклом с последующей сушкой на воздухе в течении 6 часов. Качество поверхности плакированных слоёв оценивали после 48 часов их выдержки в климатической камере при 24$28{ }^{\circ} \mathrm{C}$ с относительной влажностью воздуха $60-85 \%$.

Результаты. С увеличением длительности кратковременного хранения (до 24 ч) структурированных песчаножидкостекольных смесей на воздухе их прочность возрастает, а осыпаемость понижается. При долговременном хранении - прочность уменьшается, а осыпаемость возрастает. Хранение приготовленных песчано-жидкостекольных смесей следует проводить в герметично закрываемой таре с использованием навески гидроксида натрия. Впервые установлена кинетика карбонизации натриевого жидкого стекла в слое толщиной 20 мкм. На основе экспериментальных данных построены кинетические кривые карбонизации натриевого жидкого стекла в плакированном слое. Рассмотрены причины появления экстремума на кинетических кривых. Разработано аналитическое выражение зависимости осыпаемости структурированных песчано-жидкостекольных смесей от времени их нахождения на воздухе. Установлено, что из числа опробованных в работе технологических добавок, которые предварительно вводились в натриевое жидкое стекло, ни одна добавка не предотвращает и не замедляет процесс карбонизации дегидратированного жидкого стекла в плакированном слое.

Научная новизна. Впервые исследована кинетика карбонизации натриевого жидкого стекла в слое толщиной 20 мкм на воздухе. Установлено, что процесс карбонизации жидкого стекла начинается без индукционного периода и носит экстремальный характер. Впервые установлена аналитическая зависимость величины осыпаемости структурированных жидкостекольных смесей от времени нахождения их на воздухе.

Практическая значимость. Разработаны рекомендации по длительному хранению зернистых материалов, содержащих пылевидный силикат натрия либо плакированных силикатом натрия, Использование рекомендаций позволит сократить технологические потери и повысить качество работ по укрепления грунтов жидким стеклом, повысить качество бетонов и литья, производимого в песчано-жидкостекольных формах.

Ключевые слова: карбонизация, жидкое стекло, воздух, вода, осыпаемость, углекислый газ, влажность, прочность

Recommended for publication by Seliverstov V. Yu., Doctor of Technical Sciences. The manuscript was submitted 05.03.20. 